\title{
Diallel analysis of the duration of vegetation period in tomato (Solanum lycopersicum L.) with increased lycopene content in the fruit
}

\author{
Liudmila RUDAS ${ }^{1}$, Mariya TORBANYUK ${ }^{1,2}$, Zinoviy $\mathrm{SYCH}^{3}$
}

Received January 27, 2021; accepted March 31, 2021.

Delo je prispelo 27. januarja 2021, sprejeto 31. marca 2021.

Diallel analysis of the duration of vegetation period in tomato (Solanum lycopersicum L.) with increased lycopene content in the fruit

Abstract: Five parental forms of tomato (Solanum lycopersicum L.) and twenty hybrids $F_{1}$, were studied which were obtained by the complete diallel scheme $(5 \times 5)$. For genetic analysis (by Hayman, 1954; Jinks,1954) was used line №477 $(s p, u)$, variety Alya $(s p)$ with reduced duration of vegetation period and three collection samples with the high lycopene content in fruits: Dark Green $\left(h p-2^{d g}\right)$, MO $112(h p)$, T-3627 $\left(B^{c}\right)$. The effects of the general (GCA) and specific combining ability (SCA) of the duration of vegetation period were determined and established character of inheritance. According to the results of research, the duration of vegetation period is controlled by additive-dominant genetic system. Inheritance occurs by type of over dominance, and in dry and hot summers which led to the prolongation of the duration of vegetation period, there is a tendency to incomplete dominance, but it is apocryphal. In genetic control a major role play non-additive effects of genes. The best reliable effects of the general combining ability (GCA) had line №477 and variety Alya. They can be recommended for the creation of heterotic hybrids and varieties.

Key words: combining ability; diallel analysis; hybrid; duration of vegetation period; tomato
Dialelna analiza trajanja rastne dobe paradižnika (Solanum lycopersicum $\mathrm{L}$.) s povečano vsebnostjo likopena v plodovih

Izvleček: V raziskavi je bilo preučevanih pet starševskih linij paradižnika (Solanum lycopersicum L.) in dvajset $F_{1}$ križancev, ki so bili pridobljeni po popolni dialelni shemi ( $5 \mathrm{x}$ 5). Za genetsko analizo po metodah Haymana (1954) in Jinksa (1954) je bila uporabljena linija №477 $(s p, u)$ in sorta Alya $(s p) s$ skrajšanim trajanjem vegetacijske dobe in trije vzorci iz zbirke s povečano vsebnostjo likopena v plodovih in sicer: 'Dark Green' $\left(h p-2^{d g}\right)$, MO $112(h p)$, in T-3627 $\left(B^{c}\right)$. Določeni so bili učinki splošne (GCA) in specifične kombinacijske sposobnosti (SCA) za trajanje vegetacijske dobe in ustaljene znake dedovanja. Glede na izsledke raziskave je trajanje vegetacijske dobe nadzorovano $\mathrm{z}$ aditivno dominantnim genskim sistemom. Dedovanje se pojavlja $\mathrm{z}$ načinom naddominace, kar $\mathrm{v}$ suhih in vročih poletjih vodi do podaljšanja vegetacijske dobe. Obstaja tudi nagnenje $\mathrm{k}$ nepopolni dominanci, a tega ne moremo zagotovo potrditi. Pri genetski kontroli igrajo glavno vlogo neaditivni učinki genov. Najbolj zanesljive učinke splošne kombinacijske sposobnosti (GCA) je imela linija №477 in sorta Alya. Ti dve bi lahko priporočali za tvorbo heterotičnih križancev in sort.

Ključne besede: kombinacijska sposobnost; dialelna analiza; križanec; trajanje vegetacijske dobe; paradižnik

\footnotetext{
1 Cherkasy research station of the National Scientific Center «Institute of Agriculture of the National Academy of Agrarian Sciences of Ukraine», Dokuchaeva street, 13, Kholodnyanske, Smilyansky district, Cherkasy region, UA20731

2 Corresponding author, e-mail: mariyatr@ukr.net

3 Bila Tserkva National Agrarian University, Cathedral Square, 8/1, Bila Tserkva, Kyiv region, UA09117
} 


\section{INTRODUCTION}

Tomato is one of the most important vegetable plants, which ranks first in the world on terms of area grown in both open and protected areas (Distefano et al., 2020). In EU 2.1 million hectares of land are used for growing vegetables (Bogevska et al., 2017). The largest producer is Italy ( $35.5 \%)$. The average consumption of fresh tomato per one person is $39 \mathrm{~kg}$ on year (Cook, 2019). The fruits of this plant have high nutritional and dietary properties (Alenazi et al., 2020).

One of the main directions of tomato breeding is creation of varieties and hybrids with high content of carotenoids, in particular lycopene, which, unlike others, not only retains quality after heat treatment, but also improves them (Wai et al.,2020). Lycopene is a unique natural antioxidant that has anti-cancer properties (Timofeev et al., 1972; Sharma et al., 2019). This is a biologically active compound that can prevent damage to cells by socalled free radicals, almost three times more active than b-carotene. Lycopene is a natural remedy for the prevention of cardiovascular and cancer diseases ( $\mathrm{Li} \& \mathrm{Xu}, 2014$ Pouchieu et al., 2014; Tang et al., 2014; Li et al., 2018).

The samples of tomato with mutant genes $h p-2^{d g}, h p$, $B^{c}$, containing increased lycopene content in fruits, have a number of pleiotropic effects, including the weakening of the initial growth (Galpas et al., 2008; Samovol \& Kondratenko, 2018; Diretto et al., 2020). As a result, the seeds germinate slowly, seedling growth is slowed and weakened, which leads to prolongation of the duration of vegetation period, namely, this -determines the distribution of culture (Zhuchenko, 1991; Dannehl et al., 2021).

The main task in creating the source material of tomatoes with high lycopene content in the fruit is to reduce the duration of vegetation period. This will allow expand range of genetic diversity of tomatoes to increase efficiency of breeding work (Cimo et al., 2020).

Assessment of combining ability of parental forms allows predict the results of future crosses and focus on the creation of promising breeding material. High heterosis is manifested in those hybrid combinations in which at least one of the components of crossing is a sample with high general combining ability (GCA). The most complete and comprehensive combining ability is assessed in diallel crosses. In the work was used method of diallel analysis of quantitative features (Yates, 1947; Hayman, 1954). It is used to quickly obtain data on the nature of the inheritance of quantitative traits that are controlled by groups of genes (polygenes) (Fedin, 1970).

\section{MATERIAL AND METHODS}

The purpose of this research work was to identify parental forms with high general and specific combining ability. Genetic analysis provided parameters and character or inheritance of the duration of vegetation period.

The research was conducted in 2017-2019 in the fields of breeding and seed crop rotation of Cherkasy research station of the National Scientific Center «Institute of Agriculture of the National Academy of Agrarian Sciences of Ukraine», located in the village Kholodnyansky $\left(49^{\circ} 11^{\prime} \mathrm{N}\right.$ at $\left.31^{\circ} 52^{\prime} \mathrm{E}\right)$ Cherkasy region, Ukraine. For genetic analysis (Hayman, 1954; Jinks, 1954) were used the line №477 $(s p, u)$ and variety Alya $(s p)$ with reduced duration of vegetation period and three collection samples with high lycopene content in fruits: 'Dark Green' ( $h p$ $\left.2^{d g}\right)$, 'MO 112' $(h p)$ and 'T-3627' $\left(B^{c}\right)$.Five parental forms of tomato and twenty $\mathrm{F}_{1}$ hybrids were analysed which were obtained by the complete diallel scheme $(5 \times 5)$.

The research based on the method of one-factor experiments (Dospekhov, 1985). The duration of vegetation period (period of full germination (more than $75 \%$ of plants) prior to beginning of ripening of fruits of the first raceme) was determined according to «Methodology for conducting expertise of potato plants and groups of vegetable, melon, spicy-tasting for the expiration in Ukraine». Evaluation of combining ability regarding the duration of vegetation period was performed according to first scheme (Griffing, 1956) with the matrix of crosses and test $p 2$ (direct and reciprocal crosses + parental forms), where $\mathrm{p}$ - is the number of parental forms.

\section{RESULTS AND DISCUSSION}

The analysis of variance of a one - factor experiment made it possible to establish significant differences between hybrids. That is, of the duration of vegetation period is different, and on the combining ability can be expected differences in the studied samples, variety and line (general or specific). The sum of the squares in hybrids is due to genotypic differences (Table 1).

Parental line, variety, samples and hybrids differed in the magnitude of the expression of the trait (Table 2).

The longest duration of vegetation period were in samples 'Dark reen' (104.3-121.3 days), 'MO 112' (100.0110.7 days) and 'T-3627' (97.0-112.3 days). Shortest duration of vegetation period were in line '№477' (94.0102.0 days) and variety Alya (96-108.3). The average values in hybrids with the participation of samples 'T-3627', 'Dark Green' and 'MO 112' are the largest, and are 95.3110.9 days; 97.7-114.5 days and 95.8-110.7 days respectively. For the participation of line №477 and variety Alya 
Table 1: Analysis of variance of the duration of vegetation period

\begin{tabular}{|c|c|c|c|c|c|c|}
\hline Years & Type of scattering & Sum of squares & Degree of freedom & Middle square & F calc. & F tabl. \\
\hline \multirow{5}{*}{$\stackrel{ }{\stackrel{ }{\sim}}$} & General & 1228.0 & 74 & & \multirow{5}{*}{35.28} & \multirow{5}{*}{1.74} \\
\hline & Repetitions & 0.8 & 2 & & & \\
\hline & Genotype & 1161.3 & 24 & $48.4^{*}$ & & \\
\hline & Residual & 65.8 & 48 & 1.4 & & \\
\hline & $\mathrm{LSD}_{05}$ & & & 2.0 & & \\
\hline \multirow{5}{*}{$\stackrel{\infty}{\underset{\sim}{\circ}}$} & General & 918.0 & 74 & & \multirow{5}{*}{19.01} & \multirow{5}{*}{1.74} \\
\hline & Repetitions & 6.6 & 2 & & & \\
\hline & Genotype & 824.6 & 24 & $34.4^{*}$ & & \\
\hline & Residual & 86.8 & 48 & 1.8 & & \\
\hline & $\mathrm{LSD}_{05}$ & & & 2.2 & & \\
\hline \multirow{5}{*}{ 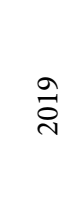 } & General & 1766.7 & 74 & & \multirow{5}{*}{14.32} & \multirow{5}{*}{1.74} \\
\hline & Repetitions & 12.4 & 2 & & & \\
\hline & Genotype & 1539.3 & 24 & $64.1^{\star}$ & & \\
\hline & Residual & 215.0 & 48 & 4.5 & & \\
\hline & $\mathrm{LSD}_{05}$ & & & 3.5 & & \\
\hline
\end{tabular}

* Significant at $5 \%$ level

Table 2: Average value of the duration of vegetation period in the parental line, variety, samples, $(\bar{x} p)$ and hybrids $\left(\bar{x} F_{1}\right)$, days

\begin{tabular}{lcccccc}
\hline & \multicolumn{7}{c}{ Years of research } \\
\cline { 2 - 7 } Line, \\
\cline { 2 - 7 } & \multicolumn{2}{c}{2017} & \multicolumn{2}{c}{2018} & \multicolumn{2}{c}{2019} \\
\cline { 2 - 8 } №477 & $\mathrm{P}$ & $\mathrm{F}_{1}$ & $\mathrm{P}$ & $\mathrm{F}_{1}$ & $\mathrm{P}$ & $\mathrm{F}_{1}$ \\
Alya & 94.0 & 93.0 & 97.3 & 98.5 & 102.0 & 105.2 \\
Dark Green & 96.0 & 94.2 & 99.3 & 100.3 & 108.3 & 109.3 \\
MO 112 & 105.3 & 97.7 & 104.3 & 102.0 & 121.3 & 114.5 \\
T-3627 & 103.3 & 95.8 & 100.0 & 102.2 & 110.7 & 110.7 \\
\hline $\bar{x}_{1}$ & 97.0 & 95.9 & 103.7 & 103.5 & 112.3 & 110.0 \\
\hline LSD $_{05}$ & 99.1 & 95.3 & 100.9 & 101.3 & 110.9 & 109.9 \\
\hline
\end{tabular}

values is lower than the averages group on the parental forms during the three years of research.

The results of analysis of variance of combining ability (Table 3 ) indicate on significant differences (general and specific).

In addition, a significant reciprocal effect over three years of research. In this case, when is a reciprocal effect, it can be eliminated by averaging the values of the trait in direct and inverse hybrids and take the same average values.

Studies have shown that by the duration of vegeta- tion period the best (in this case the lowest, negative, because it is a best indicator for the trait - a reduced period of fruit ripening) significant effects of general combining ability (GCA) for three years of research had line №477 (from minus 4.70 to minus 2.34); during two years of research variety Alya (from minus 1.11 to minus 0.99) (Table 4). Samples that have significant positive effects GCA - 'Dark Green' (from 0.74 to 4.53) and 'MO 112' (from 0.46 to 0.84 ) contribute to the prolongation duration of vegetation period. 
Table 3: Analysis of variance of the combining ability on the duration of vegetation period

\begin{tabular}{|c|c|c|c|c|c|c|}
\hline Years & Type of scattering & Sum of squares & Degrees of freedom & Middle square & F calc. & F tabl. \\
\hline \multirow{5}{*}{$\stackrel{\curvearrowright}{\stackrel{\sim}{*}}$} & Hybrids & 1161.3 & 24 & $48.4^{*}$ & 35.3 & 1.79 \\
\hline & GCA & 131.1 & 4 & $32.8^{\star}$ & 71.7 & 2.61 \\
\hline & SCA & 153.2 & 10 & $15.3^{*}$ & 33.5 & 2.08 \\
\hline & Reciprocals & 102.7 & 10 & $10.3^{*}$ & 22.5 & 2.08 \\
\hline & Residual & 22.0 & 48 & $0.5^{\star}$ & & \\
\hline \multirow{5}{*}{$\underset{\sim}{\stackrel{\infty}{\sim}}$} & Hybrids & 807.6 & 24 & $33.6^{*}$ & 19.1 & 1.79 \\
\hline & GCA & 145.8 & 4 & $36.5^{*}$ & 62.0 & 2.61 \\
\hline & SCA & 47.2 & 10 & $4.7^{\star}$ & 8.0 & 2.08 \\
\hline & Reciprocals & 76.2 & 10 & $7.6^{*}$ & 13.0 & 2.08 \\
\hline & Residual & 28.2 & 48 & $0.6^{*}$ & & \\
\hline \multirow{5}{*}{$\stackrel{\curvearrowright}{\stackrel{\gamma}{~}}$} & Hybrids & 1539.3 & 24 & $64.1^{\star}$ & 14.3 & 1.79 \\
\hline & GCA & 437.3 & 4 & $109.3^{\star}$ & 73.2 & 2.61 \\
\hline & SCA & 32.1 & 10 & $3.2^{*}$ & 2.2 & 2.08 \\
\hline & Reciprocals & 43.7 & 10 & $4.4^{*}$ & 2.9 & 2.08 \\
\hline & Residual & 71.7 & 48 & $1.5^{*}$ & & \\
\hline
\end{tabular}

* Significant at $5 \%$ level

Table 4: Evaluation of the effects of general combining ability (GCA) of the duration of vegetation period

\begin{tabular}{lccc}
\hline \multirow{2}{*}{$\begin{array}{l}\text { Line, variety, } \\
\text { samples }\end{array}$} & \multicolumn{3}{c}{ Years } \\
\cline { 2 - 4 } №477 & 2017 & 2018 & 2019 \\
\cline { 2 - 4 } Alya & $-2.34^{*}$ & $-2.76^{*}$ & $-4.70^{*}$ \\
Dark Green & $-1.11^{*}$ & $-0.99^{*}$ & -0.67 \\
MO 112 & $2.43^{*}$ & $0.74^{*}$ & $4.53^{*}$ \\
T-3627 & $0.46^{*}$ & $0.84^{*}$ & $0.80^{*}$ \\
\hline LSD $_{05}$ & $0.56^{*}$ & $2.17^{*}$ & 0.03 \\
\hline
\end{tabular}

* Significant at $5 \%$ level

Significant differences of the specific combining ability (SCA) that was observed over the years of research indicated that some hybrid combinations within the variety differed significantly from the average value and in the inheritance of traits where non-additive effects of genes were involved. In order to identify samples and varieties with high or low specific combining ability (SCA), for each parent formthe variance for comparison with the overall average value were calculated (Table 5).

We found that high (negative) reliable values of the specific combining ability (SCA) for one year of research were in line №477 (minus 0.59), samples 'MO 112' (minus 0.36) and 'Dark Green' (minus 0.22). The best values (SCA) were in hybrid combinations: '№477' / 'Dark Green' (minus 2.73), 'Dark Green' / 'MO 112' (minus 2.19), '№477’ / 'MO 112' (minus 1.59), '№ 477' / 'Alya' (minus 1.21), ‘№477’ / 'T-3627’ (minus 1.21), 'Alya’ / 'Dark Green' (minus 0.96), 'Dark Green' / 'T-3627' (minus 1.83).

Comparison o the variance of effects of the general $\left(\delta_{g 1}{ }^{2}\right)$ and specific $\left(\delta_{S i}{ }^{2}\right)$ combining ability determined that in line №477 (shortened of the duration of vegetation period, high negative significant effects of GCA) and in the sample 'Dark Green' (the longest duration of the vegetation period, low positive significant effects of GCA) years of research - the predominance of non-additive effects of genes in genetic control of the trait was observed during all three years of research.

For two years of research was established advantage of non-additive effects of genes in variety Alya and sample 'T-3627'. In sample 'MO 112' predominate additive effects of genes. 
Table 5: Estimation of variances of general combining ability (GCA) and specific combining ability (SCA) for line, variety and samples on the duration of vegetation period of 2017-2019

\begin{tabular}{|c|c|c|c|c|c|c|c|}
\hline $\begin{array}{l}\text { Line, variety, } \\
\text { sample }\end{array}$ & Years & Alya & $\begin{array}{l}\text { Dark } \\
\text { green }\end{array}$ & MO 112 & T-3627 & $\delta_{S i}^{2}$ & $\delta_{g 1}^{2}$ \\
\hline \multirow{3}{*}{ № 477} & 2017 & $1.47^{\star}$ & $-2.73^{\star}$ & $-1.59^{\star}$ & $-0,53$ & $2.76^{*}$ & 5.41 \\
\hline & 2018 & $-1.21^{\star}$ & -0.77 & $1.63^{*}$ & $-1.21^{\star}$ & $1.10^{*}$ & 7.53 \\
\hline & 2019 & -1.40 & -0.10 & 0.30 & -0.27 & -0.59 & 21.88 \\
\hline \multirow{3}{*}{ Alya } & 2017 & & $-0.96^{\star}$ & $-2.99^{\star}$ & -0.43 & $2.72^{\star}$ & 1.17 \\
\hline & 2018 & & 0.13 & -0.64 & $1.69^{\star}$ & 0.75 & 0.89 \\
\hline & 2019 & & -0.47 & $1.43^{\star}$ & 0.70 & 0.06 & 0.24 \\
\hline \multirow{3}{*}{ Dark Green } & 2017 & & & $-2.19^{\star}$ & -0.71 & $3.07^{\star}$ & 5.84 \\
\hline & 2018 & & & -0.21 & -0.71 & -0.15 & 0.46 \\
\hline & 2019 & & & 0.07 & $-1.83^{*}$ & -0.22 & 20.31 \\
\hline \multirow{3}{*}{ MO 112} & 2017 & & & & -0.33 & $3.76^{*}$ & 0.15 \\
\hline & 2018 & & & & $2.19^{\star}$ & $1.54^{\star}$ & 0.62 \\
\hline & 2019 & & & & -0.93 & -0.36 & 0.43 \\
\hline \multirow{3}{*}{ T-3627 } & 2017 & & & & & $-0.08^{*}$ & 0.25 \\
\hline & 2018 & & & & & $1.97^{\star}$ & 4.62 \\
\hline & 2019 & & & & & 0.08 & -0.21 \\
\hline \multirow{3}{*}{$\begin{array}{l}\text { Average } \\
\text { value }\end{array}$} & 2017 & & & & & 2.45 & \\
\hline & 2018 & & & & & 1.04 & \\
\hline & 2019 & & & & & -0.21 & \\
\hline
\end{tabular}

* Significant at $5 \%$ level

Note. $\delta_{S i}{ }^{2}$ - variance of the effect of specific combining ability; $\delta_{g 1}{ }^{2}$ - variance of the effect of general combining ability.

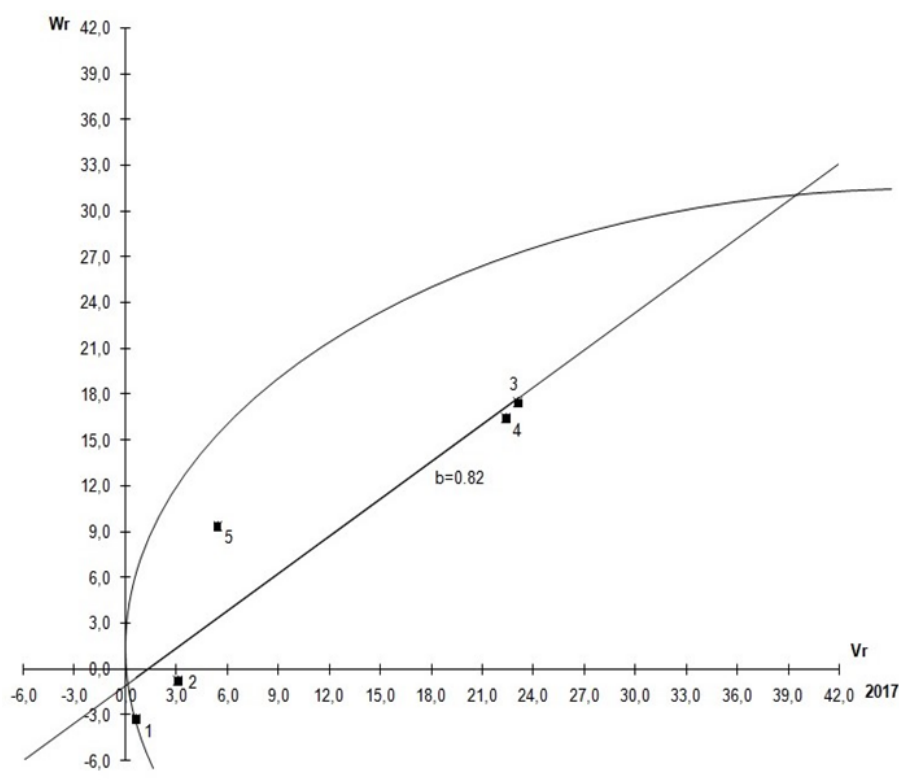

Figure 1: Graph of the dependence of $W r$ by $V r, 2017$.

1 - Line №477; 2 - Variety Alya; 3 - Sample ‘Dark Green’; 4 - Sample ‘MO 112’; 5 - Sample ‘T-3627’. 


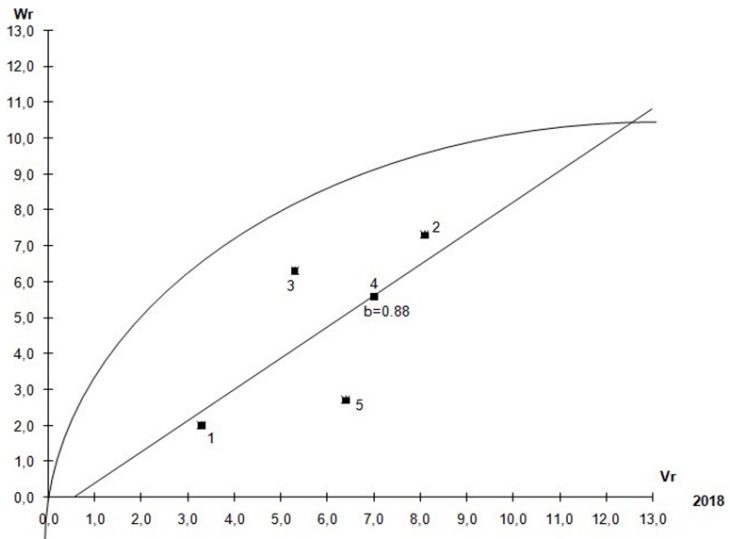

Figure 2: Graph of the dependence of $W r$ by $V r, 2018$.

1 - Line №477; 2 - Variety Alya; 3 - Sample 'Dark Green’; 4 - Sample 'MO 112'; 5 - Sample ‘T-3627'.

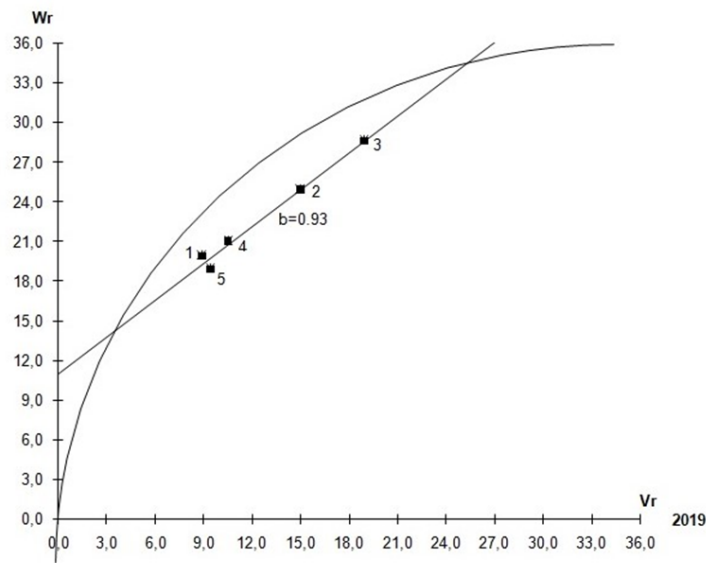

Figure 3: Graph of the dependence of $W r$ by $V r, 2017$.

1 - Line №477; 2 - Variety Alya; 3 - Sample ‘Dark Green’; 4 - Sample 'MO 112'; 5 - Sample ‘T-3627’.

Thus, it was found that line №477 and variety Alya should be used to create heterotic hybrids and varieties.

Genetic analysis (Hayman, 1954) checks the homogeneity of the difference between covariance and variance of $W r-V r$ through Student's t test did not reveal epistatic interaction of genes. Graphic analysis shows that the inheritanceof the trait duration of vegetation period involved additive and non-additive effects of genes (the regression coefficients are reliable and do not differ from one), that is, the regression line does not deviate from the unit slope line (Fig. 1-3).

This is confirmed high value of the components $D$ and $H 1$ that characterize the variability of the trait, which is due to the additive and dominant effects of genes.

Values of $\mathrm{H} 1$ and $\mathrm{H} 2$ are unequal, from which it is possible to conclude that alleles that positively and negatively determine the trait are unevenly distributed between the parental forms. The uneven ratio of genes with positive and negative effects is indicates value of $H 2 / 4 H 1$, which was $0.14-0.21$.
The parameter $\frac{\sqrt{4 D H 1+F}}{\sqrt{4 D H 1-F}}$ in 2017 and 2019 varied in the range of 1.42-1.79, which indicates an excess of dominant alleles in the studied samples; in 2018 - 0.81 - recessive alleles.

The value of parameter $D$, which measures additive variability in the population, was lower in comparison with $H 1$, which measures dominant variability over two years of research (Table 6). Values $H 1>H 2$ indicates an unequal ratio of positive and negative effects.

Positive significant values of the indicator $F(F>0)$ in 2017 and 2019 indicate the predominance of dominant alleles in the studied line, variety and samples, in 2018 prevailed recessive alleles.

For two years of research, the average degree of dominance was 1.23-1.40. The regression line intersects the negative part of the axis $W r$, so it can be argued about dominance in all loci. In 2019, in dry and hot summers degree of dominance was 0.35 , there is a tendency to incomplete dominance, but it is apocryphal. 
Table 6: Genetic parameters of the duration of vegetation period

\begin{tabular}{lccc}
\hline \multirow{2}{*}{ Parameters } & \multicolumn{3}{c}{ Years } \\
\cline { 2 - 4 } $\mathrm{D}$ & 2017 & 2018 & 2019 \\
\cline { 2 - 4 } $\mathrm{F}$ & $23.74 \pm 3.11$ & $8.27 \pm 1.29$ & $47.7 \pm 0.47$ \\
$\mathrm{H}_{1}$ & $16.59 \pm 7.77$ & $-2.19 \pm 3.23$ & $5.89 \pm 1.18$ \\
$\mathrm{H}_{2}$ & $35.87 \pm 7.90$ & $12.62 \pm 3.29$ & $5.95 \pm 1.20$ \\
$\mathrm{~h}^{2}$ & $29.73 \pm 7.62$ & $8.26 \pm 3.17$ & $3.43 \pm 1.16$ \\
$\mathrm{E}$ & $526.87 \pm 5.14$ & $4.29 \pm 2.14$ & $35.04 \pm 0.78$ \\
$\mathrm{H}_{1} / \mathrm{D}$ & $0.46 \pm 1.27$ & $0.59 \pm 0.53$ & $1.49 \pm 0.19$ \\
$\sqrt{\mathrm{H}_{1} / \mathrm{D}}$ & 1.51 & 1.53 & 0.13 \\
$\mathrm{H}_{2} / 4 \mathrm{H}_{1}$ & 1.23 & 1.24 & 0.35 \\
& 0.21 & 0.16 & 0.14 \\
$\frac{\sqrt{4 D H 1+F}}{\sqrt{4 D H 1-F}}$ & 1.79 & 0.81 & 1.42 \\
$\mathrm{~h}^{2} / \mathrm{H}_{2}$ & & & 10.21 \\
$\begin{array}{l}\text { Conditionally } \\
\text { dominant }(\mathrm{CD})\end{array}$ & 94.03 & 0.52 & \\
Conditionally & & & \\
recessive( CR) & 108.35 & & \\
\hline
\end{tabular}

Table 7: Estimation of the direction of dominance $(F)$ by the duration of vegetation period of tomato for each parental form and their hybrids

\begin{tabular}{lccc}
\hline \multirow{2}{*}{ Line,variety, samples } & \multicolumn{3}{c}{ Years } \\
\cline { 2 - 4 } №477 & 2017 & 2018 & 2019 \\
\cline { 2 - 4 } Alya & $59.38 \pm 10.58^{\star}$ & $8.73 \pm 4.40^{\star}$ & $18.62 \pm 1.61^{\star}$ \\
Dark Green & $49.33 \pm 10.58^{\star}$ & $-11.37 \pm 4.40^{\star}$ & $-3.58 \pm 1.61^{\star}$ \\
MO112 & $-26.87 \pm 10.58^{\star}$ & $-3.79 \pm 4.40^{\star}$ & $-18.66 \pm 1.61^{\star}$ \\
T-3627 & $-23.60 \pm 10.58^{\star}$ & $-5.73 \pm 4.40^{\star}$ & $13.39 \pm 1.61^{\star}$ \\
\hline
\end{tabular}

* Significant at $5 \%$ level 
Table 8: The results of correlation and regression analyzes of the duration of vegetation period

\begin{tabular}{lccc}
\hline Indicator & 2017 & 2018 & 2019 \\
\hline Correlation $(r)$ between $W r$ and $V r$ & 0.93 & 0.66 & 0.99 \\
Regression $\left(b_{1}\right)$ between $W r$ and $V r$ & 0.82 & 0.81 & 0.93 \\
Correlation $(r)$ between $\bar{x} p$ and $W r+V r$ & 0.98 & 0.20 & 0.70 \\
Regression $\left(b_{2}\right)$ between $\bar{x} p$ and $W r+V r$ & 0.24 & 0.15 & 0.59 \\
\hline
\end{tabular}

The parameter $h 2 / H 2$ indicates the number of groups of genes (more precisely, the number of effective factors) that show dominance and control the genotypic variation of the trait. It is determined in the case of a significant difference between parameters $h 2 / \mathrm{H} 2$. This difference existed in 2017 and 2019 that allowed calculate value of this indicator, which was 10.21-17.72. That is, studied samples differ in seventeen groups of genes that show the effect of dominance.

In table 7 the indicators of genetic component $\mathrm{F}$ are shown, which reflects the relative contribution of additive and dominant effects of genes in the phenotypic manifestation on the trait in $\mathrm{F}_{1}$ hybrids.

Significant positive effects for three years of research were observed in line №477 and sample 'T-3627', which indicates the predominance of dominant alleles. In the sample 'Dark Green' for three years, sample 'MO 112' and variety Alya - for two years of research - in 2017 and 2018, 2018 and 2019 recpectively, prevailed recessive alleles.

High correlation coefficients between covariance $(W r)$ and variance $(V r)$, regression coefficients $b_{1}$ between $W r$ and $V r$ indicate that the actual regression lines do not differ significantly from the unit slope (Table 8).

The correlation coefficient between the average values of parents $(\bar{x} p)$ and sum $(W r+V r)$ in 2017 and 2019 was 0.70-0.98.

The high positive value of correlation coefficient indicates the existence of a relationship between of the duration of vegetation period in line, variety and samples and the presence of recessive genes (parental forms with the longest duration of vegetation period have the largest number of recessive alleles). Indicators of the high positive correlation indicate that recessive genes determine the increase of trait, therefore prolongation of the duration of vegetation period is controlled by recessive alleles.

With participation of correlation coefficient between the mean values of parental forms (in parents $\quad(\bar{x} p)$ and sum $(W r+V r)$ the theoretical values $W_{\text {dom }}+V_{\text {dom }}$ and $W_{\text {rec }}+V_{\text {rec }}$ for line, variety and samples were determined, which had dominant and recessive alleles.

The line, variety or sample that theoretically has all dominant alleles of the studied parental forms will have
$W_{d o m}+V_{d o m} 94.04$ (2017), 99.11 (2018) and 100.96 (2019). The theoretical value of parental form with the largest number of recessive genes was 108.35 (2017), 102.52 (2018) and 125.47 (2019).

More complete information about manifestation of dominant and recessive effects was obtained using regression graphs (Fig. 1-3). If the paternal forms have many dominant genes, then its offspring $\mathrm{F}_{1}$ will have a level of trait near to it. In this case, the variance $(\mathrm{Vr})$ will be small and this sample will coincide with the regression line, near to coordinate origin.

Therefore, variety that has many recessive genes, will be placed on the regression line at the top right, as his offspring from crossing with samples that containing many dominant genes will give a large value variation (Vr). In 2017, according to the result of assessment $F_{1}$, line №477 and variety Alya approached the point with maximum dominance. Sample 'Dark Green' which had 50 percent recessive alleles approached the point with the highest recessiveness.

In 2018, the position of samples on regression graph has changed; line №477 and sample ‘T-3627' were located in zone with the highest dominance. Samples 'MO 112', 'Dark Green' and variety Alya were located in the middle area of regression line, near to zone with the greatest recessiveness.

In 2019, line №477, samples 'MO 112' and 'T-3627' were located in zone with the highest dominance. The position of variety Alya is located in the middle area of regression line; the position of sample 'Dark Green' that characterized prolongation of the duration of vegetation period is located near to zone with the greatest recessiveness.

\section{CONCLUSIONS}

Thus, it is established that the duration of vegetation period is controlled by additive-dominant genetic system. The main role in genetic control of the trait is in non-additive effects of genes. Inheritance occurs by the type of over dominance, and in dry and hot summers leeds to the prolongation of the duration of vegetation period, there is a tendency to incomplete dominance, but it is apocryphal. The direction of dominance varies from 
dominance of genes that reduce manifestation of the trait to its absence.

The study showed that the duration of vegetation period is the best reliable effects of general combining ability (GCA) for three years of research in line №477 and in two years of research in variety Alya. They can be recommended for the creation of heterotic hybrids, as well as from the above-mentioned hybrid combinations with high values of specific combining ability (SCA) - varieties.

\section{REFERENCES}

Alenazi, M.M., Shafiq, M., Alsadon, A.A., Alhelal, I.M., Alhamdan, A.M., Solieman, Talaat H.I., Ibrahim, A.A., Shady, M.R., Al-Selwey, W.A. (2020). Improved functional and nutritional properties of tomato fruit during cold storage. Saudi Journal of Biological Sciences, 27(6), 1467-1474. https://doi.org/10.1016/j.sjbs.2020.03.026

Bogevska, Z., Popsimonova, G., Agic, R., Davitkovska, M. (2017). Agronomic evaluation of tomato hybrids for glasshouse production. Journal of Agricultural, Food and Environmental Sciences, 71(2), 23-29.

Cimo, J., Aydin, E., Sinka, K., Tarnik, A., Kiss, V., Halaj, P., Tokova, L, Kotus T. (2020). Change in the length of the vegetation period of tomato (Solanum lycopersicum L.), white cabbage (Brassica oleracea L. var. capitata) and carrot (Daucus carota L.) due to climate change in Slovakia. Agronomy, 10, 1110. https://doi.org/10.3390/agronomy 10081110

Cook, E. (2019). Agriculture, Forestry and Fishery Statistics. Edition, European Commission. Statistical Office of the European Union, Publications Office of the European Union, 216p. ISSN 2363-2488

Dannehl, D., Schwend, T., Veit, D., Schmidt, U. (2021). Increase of yield, lycopene, and lutein content in tomatoes grown under continuous PAR spectrum LED lighting. Frontiers in Plant Science, 12.611236. https://doi.org/10.3389/ fpls.2021.611236

Distefano, M., Arena, E., Mauro, R.P., Brighina, S., Leonardi, C., Fallico, B., Giuffrida, F. (2020). Effects of genotype, storage temperature and time on quality and compositional traits of cherry tomato. Foods, 9.1729. https://doi.org/10.3390/ foods 9121729

Diretto, G., Frusciante, S.,Fabbri, C.,Schauer, N.,Busta, L., Wang, Z., Matas, A.,Fiore, A., Rose, J.K.C., Fernie, A.R., Jetter, R.,Mattei, B., Giovannoni, J.,Giuliano, G. (2020). Manipulation of $\beta$-carotene levels in tomato fruits results in increased ABA content and extended shelf life. Plant Biotechnology Journal, 18(5), 1185-1199. https://doi.org/10.1111/ pbi. 13283

Dospekhov, B.A. (1985). Methods of field experience. [Uch. Manual]. Moscow, Agropromizdat, 352 p. [in Russian]

Fedin, M.A. (1970). About heterosis of wheat. Moscow, Kolos, 240p. [in Russian]

Galpas, N., Wang, Q., Menda, N., Zamir, D., Hirschberg, J. (2008). Abscisic acid deficiency in the tomato mutant highpigment 3 leading to increased plastid number and higher fruit lycopene content. The Plant Journal, 53(5), 717-730. https://doi.org/10.1111/j.1365-313X.2007.03362.x

Griffing, B. (1956). Concept of general and specific combining ability in relation to diallel crossing systems. Australian Journal of Biological Sciences, 9, 463-493. https://doi. org/10.1071/BI9560463

Hayman, B. I. (1954). The theory and analysis of diallel crosses. Genetics, 39(6), 789-809. https://doi.org/10.1093/genetics/39.6.789

Jinks, I.L.(1954). The analysis of continuous variation in a diallel cross of Nicotiana rustica varieties. Genetics, 39(6), 767788. https://doi.org/10.1093/genetics/39.6.767

Li, X. \& Xu, J. (2014). Meta - analysis of the association between dietary lycopene intake and ovarian cancer risk in postmenopausal women. Scientific Reports, 4, 4885. https://doi. org/10.1038/srep04885

Li, X., Wang, Y., Chen, S., Tian, H., Fu, D.,Zhu,B., Luo,Y.\&Z hu,H. (2018). Lycopene is enriched in tomato fruit by CRISPR/Cas9 - mediated multiplex genome editing. Frontiers in Plant Science, 9, 559. https://doi.org/10.3389/ fpls.2018.00559

Pouchieu, C., Galan, P., Ducros,V., Latino-Marte, P., Hercberg, S. \& Touvier, M. (2014). Plasma carotenoids and retinol and overall and breast cancer risk: a nested case-control study. Journal Nutrition and Cancer, 66, 980-988. https://doi.org/ $10.1080 / 01635581.2014 .936952$

Samovol, O.P. \& Kondratenko, S.I. (2018).Tomato (genetic basis of breeding). Monograph; for order. O.P. Samovola, O.M. Mohylnoi. Vinnytsia: Nilan Ltd., 448 p. [in Ukrainian]

Sharma, P., Thakur, S. \& Negi, R. (2019). Recent advances in breeding of tomato - A review. International Journal of Current Microbiology and Applied Sciences, 8(3), 1275-1283. https://doi.org/10.20546/ijcmas.2019.803.151

Tang, L., Lee, A. H., Su, D. \& Binns, C. W. (2014). Fruit and vegetable consumption associated with reduced risk of epithelial ovarian cancer in southern Chinese women. $G y$ necologic Oncology, 132, 241-247. https://doi.org/10.1016/j. ygyno.2013.10.020

Timofeev, N.N., Volkova, N.N. \& Chizhov, S.T. (1972). Breeding and seed production of vegetable crops. Ed. 2nd, reworked and add.; under. ed. I.A. Prokhorov, Moscow, Kolos, 300p [in Russian]

Tkikov S.O.; Inc. Kyerenko, Z. B., Pavlyuk, N.V. (2016). Methodology for conducting expertise of potato plants and groups of vegetable, melon, spicy-tasting for the expiration in Ukraine, Ukrainian Institute of Expertise of Plant varieties, Vinnitsa, 95 p. ISBN 978-966-924-576-2. [in Ukrainian]

Wai, A.H., Naing, A.H., Lee, Do-J., Kim, Ch.K.,Chung, Mi-Y. (2020). Molecular genetic approaches for enhancing stress tolerance and fruit quality of tomato. Plant Biotechnology Reports, 14.515-537. https://doi.org/10.1007/s11816-02000638-1

Yates, F. (1947). Analysis of data from all possible reciprocal crosses between a set of parental lines. Heredity, 1, 287-301. https://doi.org/10.1038/hdy.1947.19

Zhuchenko, A.A. \& Samovol, A.P. (1991). $F_{1}$ hybrids as a target and means of breeding. Genetics, 27(10), 1801-1813 [in Russian] 